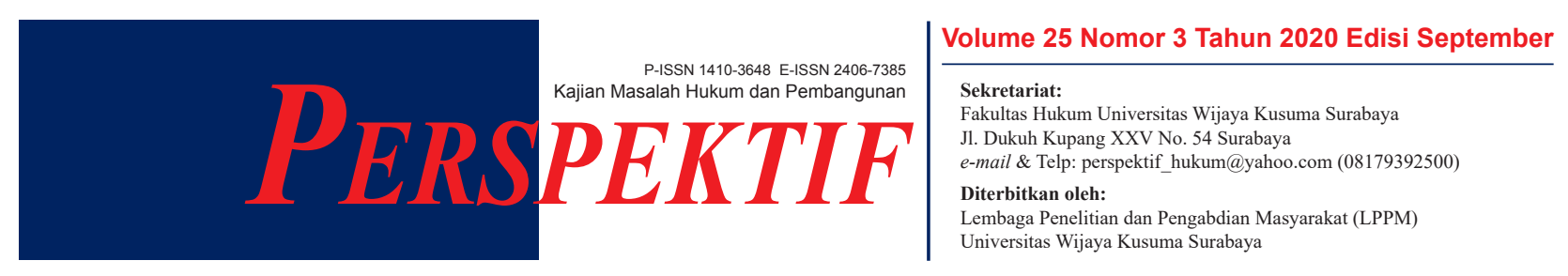

\title{
URGENSI PEMBERIAN HAK ATAS TANAH KEPADA PENANAM MODAL DALAM PERSPEKTIF TEORI HUKUM ALAM
}

\author{
Fries Melia Salviana \\ Fakultas Hukum, Universitas Wijaya Kusuma Surabaya \\ e-mail: friesmelia@gmail.com
}

\begin{abstract}
ABSTRAK
Kajian penulisan ini adalah urgensi Pemberian Hak Atas Tanah kepada Penanam Modal berdasarkan perspektif Teori Hukum Alam. Landasan pengaturannya ada pada Pasal 33 UUD 1945 bahwa pemanfaatan tanah dapat dilakukan jika digunakan untuk kesejahteraan masyarakat. Pengaturan mengenai pemberian hak atas tanah pada penanam modal asing dalam Hak Guna Bangunan, Hak Guna Usaha, dan Hak Pakai sebagaimana diatur dalam Pasal 2 UUPA. Pengaturan tersebut dalam rangka pemberian fasilitas dalam bentuk insentif berdasarkan kriteria berdasarkan Pasal 18 UU Penanaman Modal. Pemberian hak atas tanah kepada penanam modal asing telah sesuai dengan hukum alam yang mewajibkan adanya kebaikan umum guna mencapai keadilan protektif dengan adanya hak menguasai yang memberikan kewenangan untuk menentukan penataan penggunaan tanah dengan hak rakyat. Serta penanaman modal yang merupakan peningkatan modal untuk pembangunan ekonomi berkelanjutan dan peningkatan ekonomi, alih teknologi, peningkatan lapangan kerja dan pengembangan ekonomi kerakyatan. Sehingga dengan demikian berdasarkan dengan kebaikan negara, maka tentunya aturan yang telah dibuat terkait dengan pemberian hak atas tanah tersebut di atas tentunya adalah harus mensyaratkan kepedulian atas kebaikan bersama, yaitu peningkatan kesejahteraan di Indonesia.
\end{abstract}

Kata Kunci: Urgensi Pemberian Hak Atas Tanah; Penanaman Modal; Kebaikan Umum

\section{ABSTRACT}

The study in this paper is the urgency of Granting Land Rights to Investors based on the perspective of Natural Law Theory. The basis for regulating land rights is contained in Article 33 of the 1945 that use of land can used for welfare of the community. Article 2 of the UUPA also stipulates that granting land rights to foreign investors can only be granted of Building Use Rights, Business Use Rights, and Use Rights. The granting of land rights for foreign investors which is a facility in the form of incentives is regulated with a benchmark in the form of criteria contained in Article 18 Investment Law. Granting of land rights to foreign investors is in accordance with natural law which requires public good protective justice with existence of control rights which give authority to determine the arrangement of land use by taking into account people's rights to land. As well as foreign investment which is an increase in capital for sustainable economic development and economic improvement, technology transfer, increased employment and development of a people's economy. The limitations and requirements provided are also a form of protection for the community so that protective justice with a standard of general good is achieved. The recommendation given is the addition of regulations regarding the granting of land rights to foreign investors particular and use of powers related to the right to control by the government by means of restrictions in the form of requirements for granting land rights. Thus, based on the goodness of the state, of course the rules that have been made regarding the granting of rights to the land mentioned above, of course, must require concern for the common good, namely increasing welfare in Indonesia.

Keywords: Urgency Granting of Land Rights; Investors; Bonnum Commune 


\section{PENDAHULUAN}

Pertumbuhan ekonomi adalah tolok ukur dalam keberhasilan pembangunan ekonomi suatu negara. ${ }^{1}$ Salah satu permasalahan untuk pembangunan ekonomi adalah karena adanya keterbatasan modal, padahal modal sangat penting untuk melakukan pembangunan ekonomi. ${ }^{2}$ Penambahan modal dengan cara menarik penanam modal untuk menanamkan modalnya di Indonesia.

Tahun 2018, penanaman modal asing di Indoensia mengalami penurunan. Nilai investasi triwulan I mencapai sebesar Rp. 108,9 triliun yaitu Rp. 13.400 menjadi 12,12 \% pada triwulan II menjadi 95, 7 triliun. Kemudian kembali Rp. 89, 1 triliun pada triwulan III. ${ }^{3}$

Penurunan Penanaman Modal Asing ini membuat pemerintah menetapkan berbagai kebijakan untuk memberikan fasilitas terhadap penanam modal asing yang berupa insentif untuk merangsang penanam modal asing. Salah satu insentif tersebut adalah insentif terkait dengan Pemberian Hak Atas Tanah kepada Penanam Modal Asing.

Penanaman Modal Asing secara langsung merupakan penanaman modal dimana penanam modalnya hadir secara langsung, mendirikan suatu badan usaha. Pendirian badan usaha tersebut menyebabkan bahwa kepemilikan hak atas tanah bagi Penanam Modal Asing adalah hal yang sangat penting. Sehingga pemerintah memberikan fasilitas berupa insentif kepada penaman modal asing dalam kaitannya dengan pemberian Hak Atas Tanah yang diatur pada Pasal 21 Undang-Undang No. 25 Tahun 2007 tentang Penanaman Modal, selanjutnya disebut UU Penanaman Modal dan deregulasi Oktober 1992 yang merupakan kebijakan dalam sektor keuangan, moneter dan perbankan, kebijakan sektor perdagangan dan kebijakan peningkatan efisiensi serta Undang-Undang No. 2 Tahun 2012 tentang Pengadaan Tanah bagi Pembangunan untuk Kepentingan Umum.

Hak Atas Tanah adalah penting bagi masyarakat. Oleh sebab itu kebijakan terkait dengan Hak Atas

\footnotetext{
${ }^{1}$ N. Gregory Mankiw. (2007). Makro Ekonomi, Edisi Keenam. Jakarta: Erlangga, h. 182.

${ }^{2}$ Imam Muklis. (2015). Ekonomi Keuangan dan Perbankan Teori dan Aplikasi. Jakarta: Salemba Empat, h. 122.

${ }^{3}$ Administrator. Realisasi Investasi. Diakses pada https:// www.bkpm.go.id/id/statistik/investasi-langsung-luar-negeri-fdi, diakses pada 4 Agustus 2020.
}

Tanah untuk Penanam Modal Asing akan dapat menimbulkan dampak yang merugikan bagi masyarakat. Sedangkan menurut Thomas Aquinas tidak pernah bertujuan untuk dirinya sendiri tetapi untuk warga atau lebih tepatnya untuk kebaikan bersama (sinis autem legis est bonum commune) yang dalam hal ini merupakan kebaikan bersama atau yang dikatakan sebagai kebaikan negara sehingga mencapai kesejahteraan masyarakat. Sehingga perlu kiranya untuk menemukan urgensi dari pemberian Hak Atas Tanah berdasarkan perspektif Teori Hukum Alam.

\section{PERUMUSAN MASALAH}

Berkaitan dengan uraian pendahuluan di atas, maka rumusan masalah dalan penulisan ini adalah urgensi Pemberian Hak Atas Tanah kepada Penanam Modal berdasarkan perspektif Teori Hukum Alam.

\section{METODE PENELITIAN}

Metode penelitian yang dipergunakan merupakan metode penelitian secara normatif dengan melakukan pendekatan melalui perundang-undangan serta pendekatan secara konseptual.

\section{Karakteristik Hukum dari Pemberian Hak Atas Tanah Kepada Penanam Modal Asing}

Penanaman Modal Asing berdasarkan Pasal 1 angka 3 UU Penanaman Modal merupakan kegiatan penanaman modal dengan usaha di Indonesia oleh asing dengan modal sepenuhnya atau patungan.

Penanam modal asing sendiri menurut Pasal 1.6. UU Penanaman Modal merupakan perseorangan warga negara asing, badan usaha asing, dan/atau pemerintah asing yang melakukan penanaman modal di wilayah negara Republik Indonesia.

Pasal 42 dan Pasal 45 Undang-Undang No. 5 Tahun 1960 tentang Ketentuan Pokok-Pokok Agraria, (selanjutnya disingkat UUPA) menyatakan bahwa orang asing di Indonesia hanya boleh memiliki tanah menggunakan Hak Pakai atau Hak Sewa untuk Bangunan.

Fasilitas dalam bentuk jaminan dan insentif tujuannya sama untuk menarik penanam modal dan memberikan iklim investasi yang kondusif bagi investor. Investor seperti layaknya pengusaha selalu menghitung segala sesuatu dari sisi biaya. Untuk 
itu, fasilitas diberikan dalam dua bentuk, yaitu bentuk jaminan dan dalam bentuk insentif. Jaminan diberikan dengan tujuan memberikan rasa aman bagi penanam modal sedangkan insentif merupakan perangsang agar investor bersedia untuk melakukan penanaman modal di negaranya. ${ }^{4}$ Pemberian Hak atas Tanah kepada Penanam Modal merupakan salah satu dalam bentuk Insentif kepada penanam modal.

Landasan hukum yang mengatur mengenai pemberian hak atas tanah ini diatur dalam UndangUndang Dasar 1945 (selanjutnya disingkat UUD 1945) khususnya Pasal 33 ayat (3) yang menyatakan bahwa bumi, air, serta kekayaan alam yang terkandung di dalamnya dikuasai oleh negara dan digunakan sebesar-besarnya untuk kemakmuran rakyat.

Ketentuan dari UUD 1945 tersebut dijabarkan lebih lanjut dalam Undang-Undang Nomor 5 Tahun 1960 tentang Undang-Undang Pokok Agraria (selanjutnya disingkat UUPA) yang menyatakan bahwa bumi, air, dan ruang angkasa termasuk kekayaan alam yang terkandung di dalamnya itu pada tingkatan teringgi dikuasai oleh negara, sebagai organisasi kekuasaan seluruh rakyat. Sehingga pemerintah memiliki hak menguasai dengan kewenangan untuk mengatur dan menyelengggarakan baik untuk peruntukan, penggunaan persediaan dan pemeliharaan, hubungan hukum dengan orangorang, atau perbuatan-perbuatan hukum yang terkait dengan bumi, air, dan ruang angkasa. Pasal 55 ayat 2 UUPA menegaskan adanya larangan pemberian kepada penanam modal asing dengan status Hak Milik, sehingga hanya bisa dengan status Hak Guna Bangunan yaitu hak untuk mendirikan bangunan di atas tanah yang bukan merupakan milik sendiri yang terdapat di dalam Pasal 35 ayat (2) jo Pasal 36 UUPA, Hak Guna Usaha atau hak untuk mengusahakan tanah yang dikuasai langsung oleh negara dalam jangka 35 tahun yang terdapat di dalam Pasal 29 UUPA guna pengusahaan pertanian, perikanan, datau peternakan, serta Hak Pakai, yaitu hak untuk menggunakan dan atau memungut hasil dari tanah yang dikuasai langsung oleh negara atau tanah milik orang lain.

Pemberian hak atas tanah kepada Penanam modal merupakan insentif yang merupakan salah satu

\footnotetext{
${ }^{4}$ Rahmi Jened. (2016). Teori dan Kebijakan Hukum Investasi Langsung (Direct Investment). Jakarta: Kencana, h. 121.
}

bentuk dari Fasilitas Penanaman Modal. Fasilitas diatur dalam Pasal 18 UU Penanaman Modal.

Pasal 18 UU Penanaman Modal mengatur tentang kriteria pemberian fasilitas, cukup salah satu saja, yaitu membutuhkan tenaga kerja banyak, skala prioritas tunggu, pembangunan infrastruktur, termasuk alih teknologi dan atau industri pionir, di daerah terpencil, daerah tertinggal, daerah perbatasan, atau daerah lain yang dianggap perlu, melestarikan lingkungan, merupakan kegiatan penelitian, pengembangan, dan inovasi, punya mitra usaha mikro, kecil, menengah atau koperasi, modal diproduksi dalam negeri.

Persyaratan untuk pemberian hak-hak atas tanah tersebut adalah dilakukan jangka panjang dan merubah struktur perekonomian Indonesia menjadi lebih punya daya saing, tingkat resiko pengembalian panjang, area luas, hak atas tanah negara, keadilan masyarakat dan kepentingan umum. Evaluasi terkait hak atas tanah tersebut berhubungan dengan penggunaan tanah yang masih dapat dilakukan dengan baik sesuai dengan keadaan, sifat, dan tujuannya.

Pembatalan pemberian dan perpanjangan hak atas tanah akan dilakukan apabila penanam modal melakukan penelantaran dan menggunakan tidak sesuai dengan tujuan pemberian, merugikan kepentingan umum, dan melanggar aturan perundangundangan.

\section{Urgensi Pemberian Hak Atas Tanah Kepada Penanam Modal Asing Berdasarkan Perspektif Teori Hukum Alam}

Hukum alam disebut dengan "Natural Law" dan "Jus Naturale". Istilah "natura" dalam bahasa latin atau istilah "Quoic" dalam bahasa Yunani, memang berarti "alam", yaitu alam semesta (universe) secara fisik. Adapun ketika bangsa Yunani klasik mengartikan "alam" dalam sistem hukum alam, maka kata "alam" tersebut di samping berarti fisik alam semesta, juga ditambah dengan pengertian "moral" ke dalamnya, sehingga hukum alam dapat berarti fenomena moral dari manusia dan masyarakat yang dapat ditangkap melalui gejala alam fisika. ${ }^{5}$

Eksistensi hukum alam di sepanjang masa selalu memberikan makna dan fungsi tertentu hukum

\footnotetext{
${ }^{5}$ Munir Fuady. (2013). Teori-Teori Besar (Grand Theory) Dalam Hukum. Jakarta: Kencana, h. 14.
} 
alam, doktrin-doktrin hukum alam mestinya selalu mewarnai dan memberi inspirasi terhadap hukum positif, agar hukum positif selalu berjalan di rel yang benar, baik ketika dibuatnya undang-undang, ketika dijalankan undang-undang maupun ketika hakim akan memutus perkara di pengadilan. Hal itu sebab konsep hukum alam yang berwatak ganda sebagai pelindung hak, kebebasan, kemerdekaan, dan kesamaan manusia dan sekaligus sebagai perekat dari suatu solidaritas sosial. ${ }^{6}$

Menurut Thomas Aquinas, hukum itu merupakan suatu aturan, kaidah dan ukuran dari tindakantindakan manusia (lex quaedam regula est et mensura actuum). Aturan tersebut berkaitan erat dengan apa yang harus kita lakukan dan apa yang tidak boleh atau suatu larangan dengan menggunakan standar yaitu sebuah akal budi (lex sit aliquid pertinens ad rationem). ${ }^{?}$

Aturan dan ukuran akal budi ini harus sampai pada suatu tujuan akhir yang nantinya akan menjadi tujuan dari hukum yaitu kebaikan umum (bonum commune). Terkait dengan kebaikan umum, maka Thomas menjelaskan dengan komunitas sempurna (communitatis perfectae) dan hukum harus dihubungkan dengan kebahagiaan universal (felicitatum commune). Sehingga dalam hal ini hukum harus mengakomodasi semua anggota masyarakat untuk menciptakan suatu kebaikan tanpa mengeksklusi orang atau pihak lain. ${ }^{8}$

Kebaikan umum yang diciptakan dengan memberikan pengayoman kepada manusia pribadi dan masyarakat dengan cara membatasi kebebasan dan kesewenang-wenangan yang merupakan tolok ukur dari adanya keadilan protektif (iustisia protectiva). Keadilan sendiri merupakan aksiologi hukum dari aliran hukum alam. ${ }^{9}$

Hukum alam memiliki pendapat bahwa keabsahan dari kaidah-kaidah hukum positif haruslah di ukur dengan kriteria-kriteria yang lebih luas, lebih permanen, lebih fundamental, yaitu hukum alam. ${ }^{10}$

\footnotetext{
6 ibid.

7 Simplesius Sandur. (2019). Filsafat Politik dan Hukum Thomas Aquinas. Yogyakarta: Kanisius, h. 229.

8 ibid.

${ }^{9}$ I Dewa Gede Atmadja. (2013). Filsafat Hukum, Dimensi dan Historis. Malang: Setara Press, h. 73.

${ }^{10}$ Munir Fuady. op.cit., h. 48.
}

Aturan adalah bentuk formal yang digunakan sebagai wadah atau tempat bagi kaidah norma hukum. Dengan kata lain, norma atau kaidah merupakan isi dari aturan sedangkan aturan menunjuk pada bentuk formal produk hukum yang dikeluarkan oleh organ atau badan yang memiliki kewenangan untuk itu. ${ }^{11}$

Pengaturan terkait dengan pemberian hak atas tanah bagi penanam modal asing juga harus sesuai dengan hukum alam dan tentunya harus mencapai kebaikan umum (bonum commune) yang merupakan tolok ukur dari tercapainya keadilan (iustisia protectiva). Sebenarnya tujuan tersebut tersirat dalam landasan hukum yang pertama, yaitu Pasal 33 ayat (3) UUD 1945 yaitu pencapaian kemakmuran rakyat sebagai tujuan dari penggunaan bumi, air serta kekayaan alam.

Pada Pasal 2 UUPA menyatakan bahwa pemerintah memiliki hak menguasai memiliki kewenangan untuk menentukan penataan penggunaan tanah berdasarkan hak-hak rakyat terkait dengan tanah, fungsi sosial dalam pertanian dan perkotaan serta pencegahan penelantaran tanah guna tercapainya kemakmuran rakyat. Kemakmuran ini dapat dimaknai sebagai kebahagiaan, kesejahteraan, dan kemanfaatan dalam masyarakat dan negara hukum yang merdeka.

Penggunaan tanah untuk penanam modal dapat dikatakan sebagai salah satu bentuk untuk pencapaian sebesar-besarnya kemakmuran rakyat yang merupakan perwujudan dari kebahagiaan umum ini dapat dilihat dari fungsi dari adanya penanaman modal asing di Indonesia. Sebab dengan adanya penanaman modal asing dapat meningkatkan perekonomian Indonesia.

Peningkatan perekonomian di Indonesia tersebut dapat dilihat dari adanya penerapan teknologi baru dan tata cara pemasaran di berbagai bidang ekonomi, sehingga bisa meningkatkan pendapatan dari berbagai bidang ekonomi dengan perbaikan sarana prasarana yang menunjang kehidupan masyarakat serta meningkatkan kemampuan daya saing dunia usaha. Perubahan kelembagaan yang tindak lanjut dari adanya teknologi baru yang menimbulkan kebijaksanaan dalam pengelolaan perekonomian

${ }^{11}$ Yovita Arie Mangesti dan Slamet Suhartono. (2020). Ilmu Hukum Kontemporer, Menembus Batas Kekakuan Hukum Normatif. Malang: Setara Press, h. 60. 
nasional sebab kesulitan modal yang dialami oleh pemerintah sudah berkurang.

Penanaman modal asing juga dapat menambah modal bagi pemerintah untuk melakukan pembangunan sehingga pemerintah dapat melakukan pembangunan ekonomi berkelanjutan.

Kemitraan dengan Unit Usaha Mikro, Kecil, Menengah dan Koperasi yang merupakan salah satu persyaratan dalam kriteria fasilitas baik berupa jaminan atau insentif yang diatur dalam Pasal 18 UU Penanaman Modal dapat mendorong pengembangan ekonomi kerakyatan.

Penanaman modal asing secara langsung, berdasarkan Pasal 5 UU Penanaman Modal yang menerapkan adanya kewajiban untuk mendirikan perusahaan sesuai hukum Indonesia merupakan bantuan untuk pemecahan masalah kurangnya lapangan pekerjaan yang ada di Indonesia. ${ }^{12}$

Pemberian hak atas tanah yang merupakan suatu bentuk fasilitas berupa insentif juga menerapkan adanya kriteria yang terdapat di dalam Pasal $18 \mathrm{UU}$ Penanaman Modal sehingga tidak serta merta semua penanam modal asing mendapatkan insentif tersebut juga merupakah salah satu bentuk perlindungan hukum kepada kebaikan umum dari masyarakat. Pembatasan lainnya terdapat di dalam Pasal 22 ayat (3) dan ayat (4) UU Penanaman Modal mengatur tentang evaluasi perbaran hak dan tanah dapat digunakan. Serta dapat dihentikan apabila perusahaan penanam modal asing melakukan penelantaran tanah, dan hal lainnya yang dilarang dalam aturan perundang-undangan.

\section{PENUTUP}

\section{Kesimpulan}

Landasan pengaturan hak atas tanah terdapat dalam Pasal 33 UUD 1945 bahwa pemanfaatan tanah dapat dilakukan jika digunakan untuk kesejahteraan masyarakat sebagaimana diatur dalam Pasal 2 UUPA. UUPA juga mengatur bahwa pemberian hak atas tanah kepada penanam modal asing hanya dapat diberikan dalam bentuk Hak Guna Bangunan, Hak Guna Usaha, dan Hak Pakai. Pemberian Hak atas Tanah penanam modal asing yang merupakan fasilitas dalam bentuk insentif diatur dalam Pasal 21, Pasal 22, dan Pasal 23 UU Penanaman Modal

\footnotetext{
${ }^{12}$ Aminussin Ilmar. (2006). Hukum Penanaman Modal di Indonesia. Jakarta: Kencana, h. 179.
}

dengan tolok ukur berupa kriteria yang terdapat dalam Pasal 18 UU Penanaman Modal. Pemberian hak atas tanah kepada penanam modal asing telah sesuai dengan hukum alam yang mewajibkan adanya kebaikan umum guna mencapai keadilan protektif dengan adanya hak menguasai yang memberikan kewenangan untuk menentukan penataan penggunaan tanah dengan memperhatikan hak-hak rakyat atas tanah. Serta penanaman modal asing yang merupakan peningkatan modal untuk pembangunan ekonomi berkelanjutan dan peningkatan ekonomi, alih teknologi, peningkatan lapangan kerja dan pengembangan ekonomi kerakyatan. Pembatasan dan Persyaratan yang diberikan juga merupakan salah satu bentuk perlindungan bagi masyarakat agar keadilan protektif dengan tolok ukur kebaikan umum tercapai.

\section{Rekomendasi}

Pemberian hak atas tanah terkait dengan Penanaman Modal yang ada pada saat ini hanya diatur pada UU Penanaman Modal dan UU Agraria, serta Peraturan Pemerintah Pemilikan Rumah Tempat Tinggal atau Hunian oleh Orang Asing yang Berkedudukan di Indonesia. Di dalam tiga aturan hukum tersebut tidak ada pengaturan mengenai pemberian hak atas tanah kepada penanam modal asing secara khusus, sehingga perlu kiranya untuk dibuat aturan tersebut baik dalam bentuk undangundang dan aturan pelaksanaannya untuk lebih menjamin asas kepastian hukum.

Kebaikan umum sebagai tolok ukur tercapainya keadilan protektif dapat terjadi apabila pemerintah yang memiliki hak menguasai dan memiliki kewenangan dapat menjalankan fungsi kewenangannya dengan baik berdasarkan aturan perundang-undangannya terkait dengan pembatasan yang berupa kriteria persyaratan terkait dengan pemberian hak atas tanah kepada penanam modal asing.

\section{DAFTAR PUSTAKA}

\section{Peraturan Perundang-undangan:}

Undang-Undang Dasar 1945.

Undang-Undang Nomor 5 Tahun 1960 tentang Undang-Undang Pokok Agraria.

Undang-Undang Nomor 25 Tahun 2007 tentang Penanaman Modal. 
Pemerintah Republik Indonesia Nomor 103 Tahun 2015 tentang Pemilikan Rumah Tempat Tinggal atau Hunian oleh Orang Asing yang Berkedudukan di Indonesia.

\section{Buku:}

Aminussin Ilmar. (2006). Hukum Penanaman Modal di Indonesia. Jakarta: Kencana.

I Dewa Gede Atmadja. (2013). Filsafat Hukum, Dimensi dan Historis. Malang: Setara Press.

Imam Muklis. (2015). Ekonomi Keuangan dan Perbankan: Teori dan Aplikasi. Jakarta: Salemba Empat.

Munir Fuady. (2013). Teori-Teori Besar (Grand Theory) Dalam Hukum. Jakarta: Kencana.
N. Gregory Mankiw. (2007). Makro Ekonomi, Edisi Keenam. Jakarta: Erlangga.

Rahmi Jened. (2016). Teori dan Kebijakan Hukum Investasi Langsung (Direct Investment). Jakarta: Kencana.

Simplesius Sandur. (2019). Filsafat Politik dan Hukum Thomas Aquinas. Yogyakarta: Kanisius.

Yovita Arie Mangesti dan Slamet Suhartono.(2020). Ilmu Hukum Kontemporer, Menembus Batas Kekakuan Hukum Normatif. Malang: Setara Press.

\section{Website:}

Administrator. Realisasi Investasi. Diakses pada https://www.bkpm.go.id/id/statistik/investasilangsung-luar-negeri-fdi, diakses pada 4 Agustus 2020. 